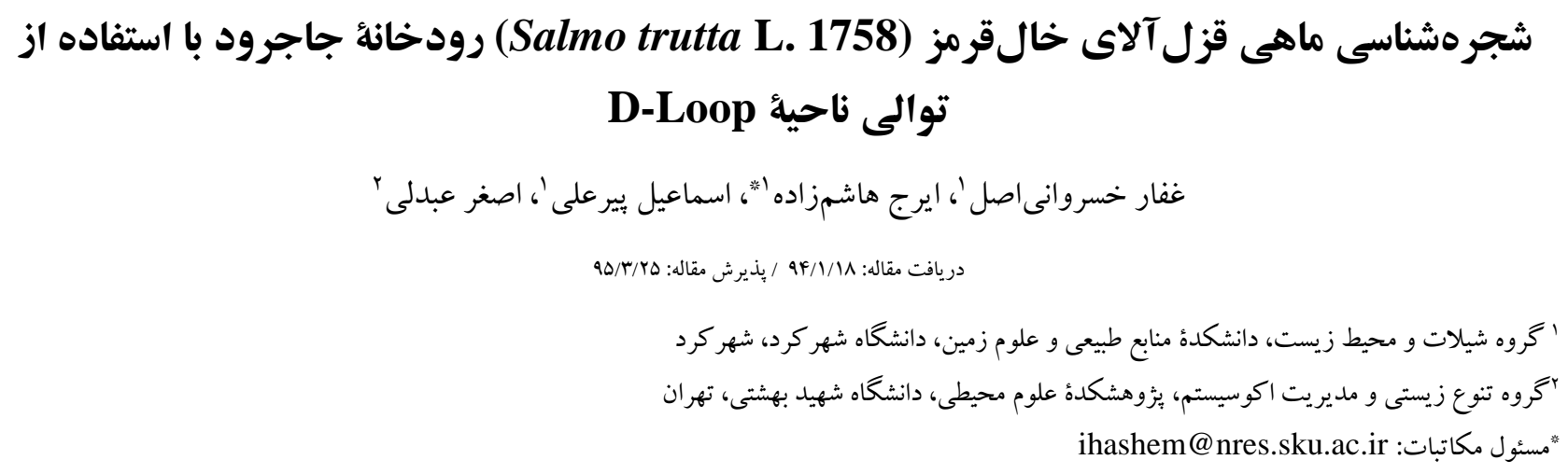

جكيده. در اين بررسى روابط شجرهشناسى ماهى قزل آلاى خالقرمز Salmo trutta L.1758 در رودخانهُ جاجرود حوضةٌ درياجُه نمكك با استفاده از توالى كامل

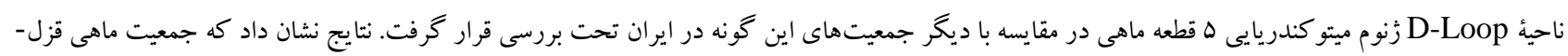

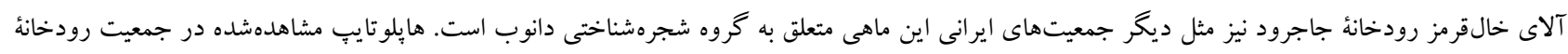

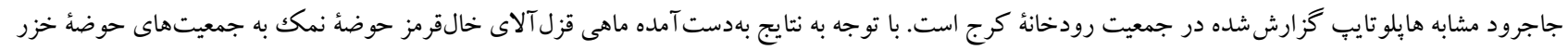

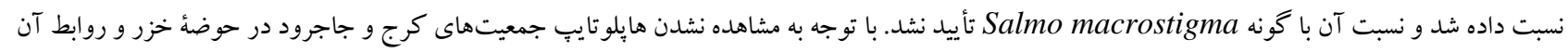

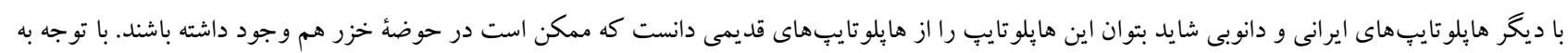

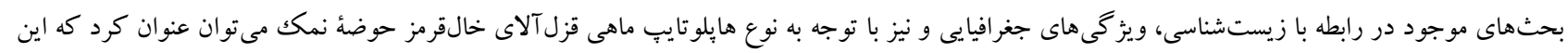

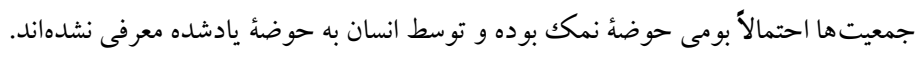
وازههاى كليدى. زُنوم ميتو كندرى، ماهى قزل آلا، حوضة خزر، هإيلو تايب قديمى، بومى

\title{
The phylogenetic position of Brown trout (Salmo trutta L.) in the Jajrud River using D-Loop sequence
}

\author{
Seyed Ghafar Khosravani Asl ${ }^{1}$, Iraj Hashemzadeh Segherloo ${ }^{2 *}$, Esmaeil Pirali ${ }^{3}$, Asghar Abdoli ${ }^{3}$ \\ Received: 06/04/2015 / Accepted: 12/06/2016
}

\begin{abstract}
${ }^{1}$ Department of Fisheries and Environmental Sciences, Faculty of Natural resources and Earth sciences, Shahr-e-Kord University, Shahr-e-Kord, Iran

${ }^{2}$ Department of Biodiversity and Ecosystem Management, Environmental Sciences Research Centre, Shahid Beheshti University, Tehran, Iran

*Corresponding author: ihashem@nres.sku.ac.ir
\end{abstract}

\begin{abstract}
In this study the phylogenetic relationship of the Jajrud River Brown trout Salmo trutta L. 1758 in the Namak Lake basin was analyzed using complete D-Loop sequence of the mitochondrial genome, in comparison with other Iranian populations of the species. According to the results, Jajrud brown trout, like other Iranian brown trout populations, belongs to the Danube phylogenetic lineage. The observed haplotype in the Jajrud population is similar to the reported haplotype in the Karaj River. The results showed that the Namak Lake basin brown trout affined to the Caspian populations, while its relationship to Salmo macrostigma was not confirmed. Although the Karaj and Jajrud River haplotypes have not been observed in the Caspian Sea basin, because of its relationship to other Iranian and Danube haplotypes, it is plausible to consider this haplotype as an old haplotype that also may exist in the Caspian Sea basin. According to the biology of brown trout, geographic characteristics, and based on the properties of the Namak haplotype, it may be inferred that the Namak basin brown trout populations are native to the habitat and not introduced.
\end{abstract}

Keywords. mitochondrial genome, trout, Caspian basin, old haplotype, native 
آلاى خالقرمز حوضهٔ نمك احتمالاً ازطريق حوضذهاى آبريز

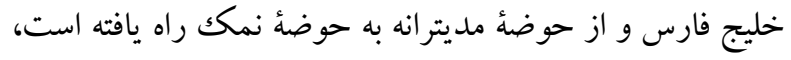

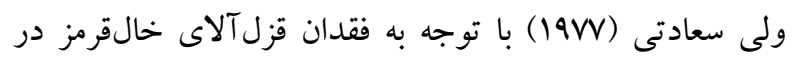
حوضةٔهاى آبريز خليج فارس و همجنين با توجه به شباهتهاى

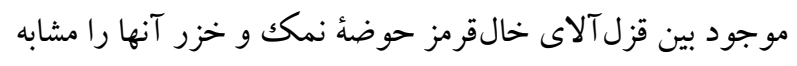

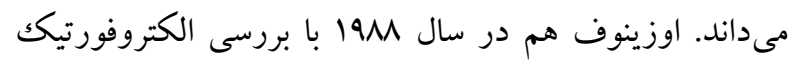

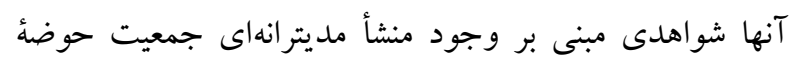

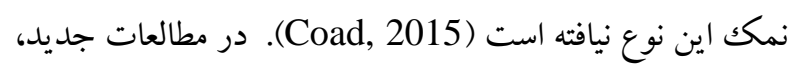

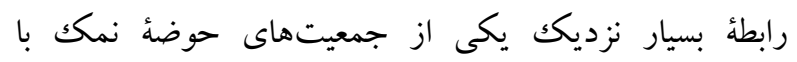
جمعيتهاى حوضهُ خزر و اروميه تأييد شد ( Hashemzadeh

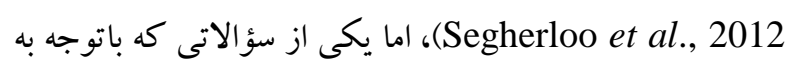

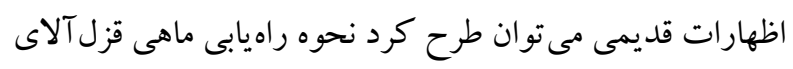

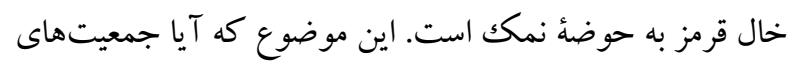

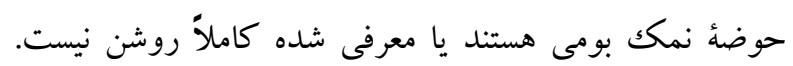

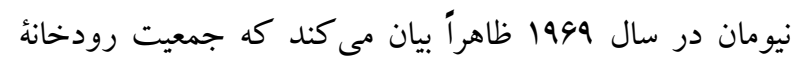

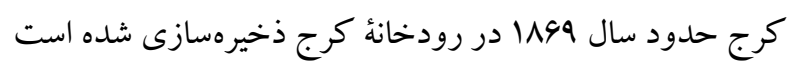

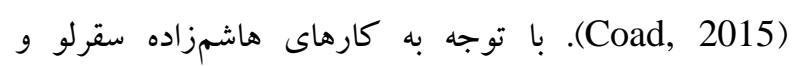

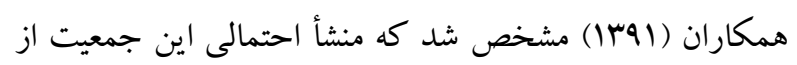
حوضة خزر است اما در مورد معرفى شدن اين جمعيت و منشأ

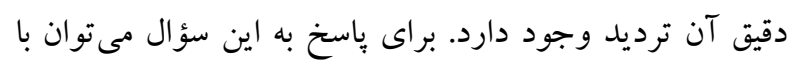
بررسى ديخر جمعيتهاى حوضة نمكك و مقايسة آنها با جمعيت كرج و نيز با بررسى جمعيتهاى حوضهُ خزر كهو كه ازنظر

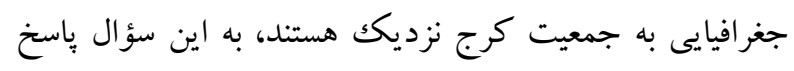

در اين مطالعه تلاش شده است با بررسى جمعيت رودخانه

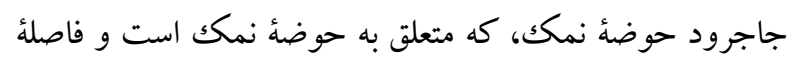

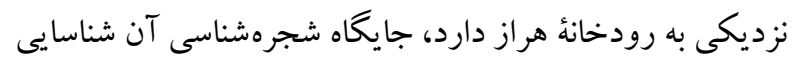
شود و رابطه و نقش احتمالى آن در انتقال ماهى قزل آلاى خالقرمز به حوضة نمكك مورد بحث قرار گيرد.

مواد و روشها

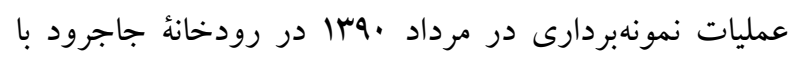

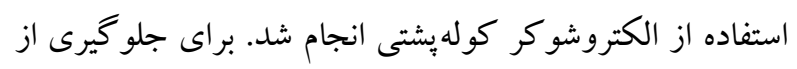

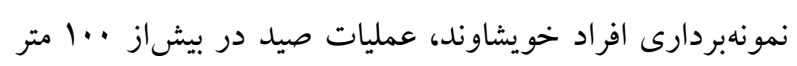
از طول رودخانه انجام شد (شكل ()). در زمان نمونهبردارى باله سينهاى و يا بالهُ شكمى يكك سمت بدن ماهى ها قطع شد و و در

\section{مقدمه}

ماهى قزل آلاى خالقرمز Salmo trutta L. 1758 متعلق به

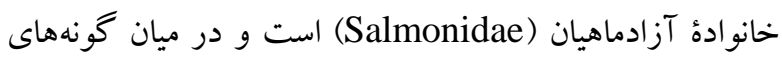

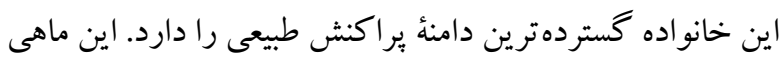
از ايسلند در غرب تا سرجشمهاى رودخانه آمودريا در ارتفاعات افغانستان در شرق و از شمال كشورهاى روسيه و نروز تا كوههاى اطلس در شمال قاره آفريقا بهصورت طبيعى قابل

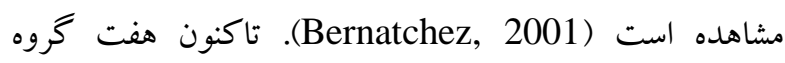

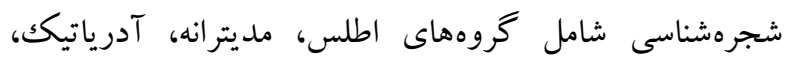

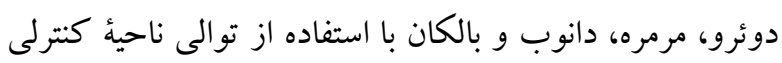

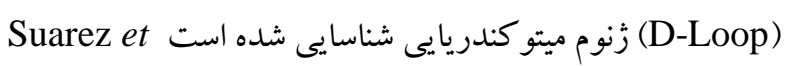
Maric et al., 2006(al., 2001; بومى اين ماهى در سه حوضئ خزر، اروميه و نمكك وجود دارند

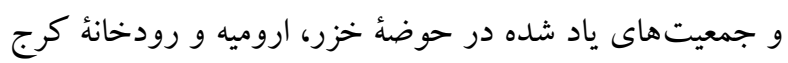

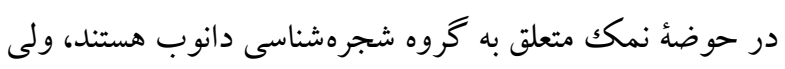

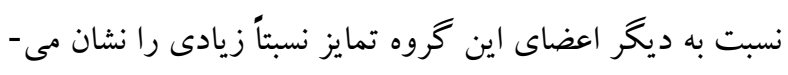
دهند (Hashemzadeh Segherloo et al., 2012). كفتنى است كه گونه Salmo trutta داراى سه شكل بومشناختى

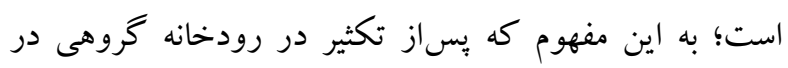

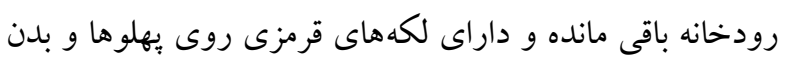

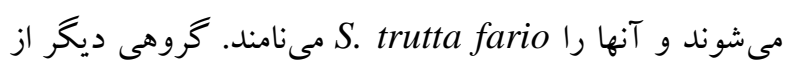
بجهماهيان بعد از مدتى زيست كذرانى در رودخانه به محيطهاى S. trutta caspius دريايى مهاجرت مى كند كه آنها

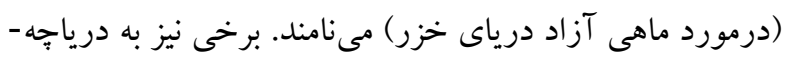

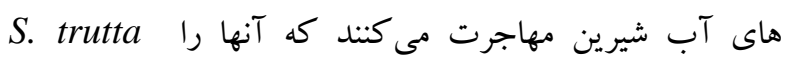
lacostris

در منابع موجود جمعيتهاى اروميه و خزر جمعيتهاى بومى

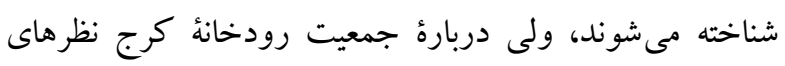
متفاوتى مطرح شده است (Coad, 2015). سعادتى (19VV)

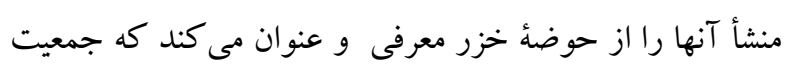
حوضة نمكك نزاد متمايز ماهى آزاد درياى خزر caspius S. trutta macro stigma قزل آلاى خالقرمز حوضةً نمك دان دانستهاند كه اولينبار در كشور الجزاير مورد بررسى و توصيف حوصن شده است (Coad, 2015). همجنين بيان شده است كه قزل- 


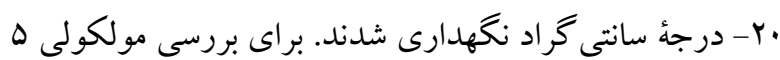
نمونه از بالههاى يادشده استفاده شد.

الكل اتانول وه درصد جهت بررسىهاى مولكولى تثبيت شد.

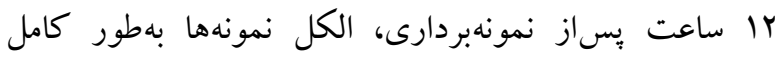
تعويض شد. با توجه به اينكه حتى در الكل در دماى معمولى نيز ممكن است DNA تخريب شود، نمونهاى يادشده در فريزر

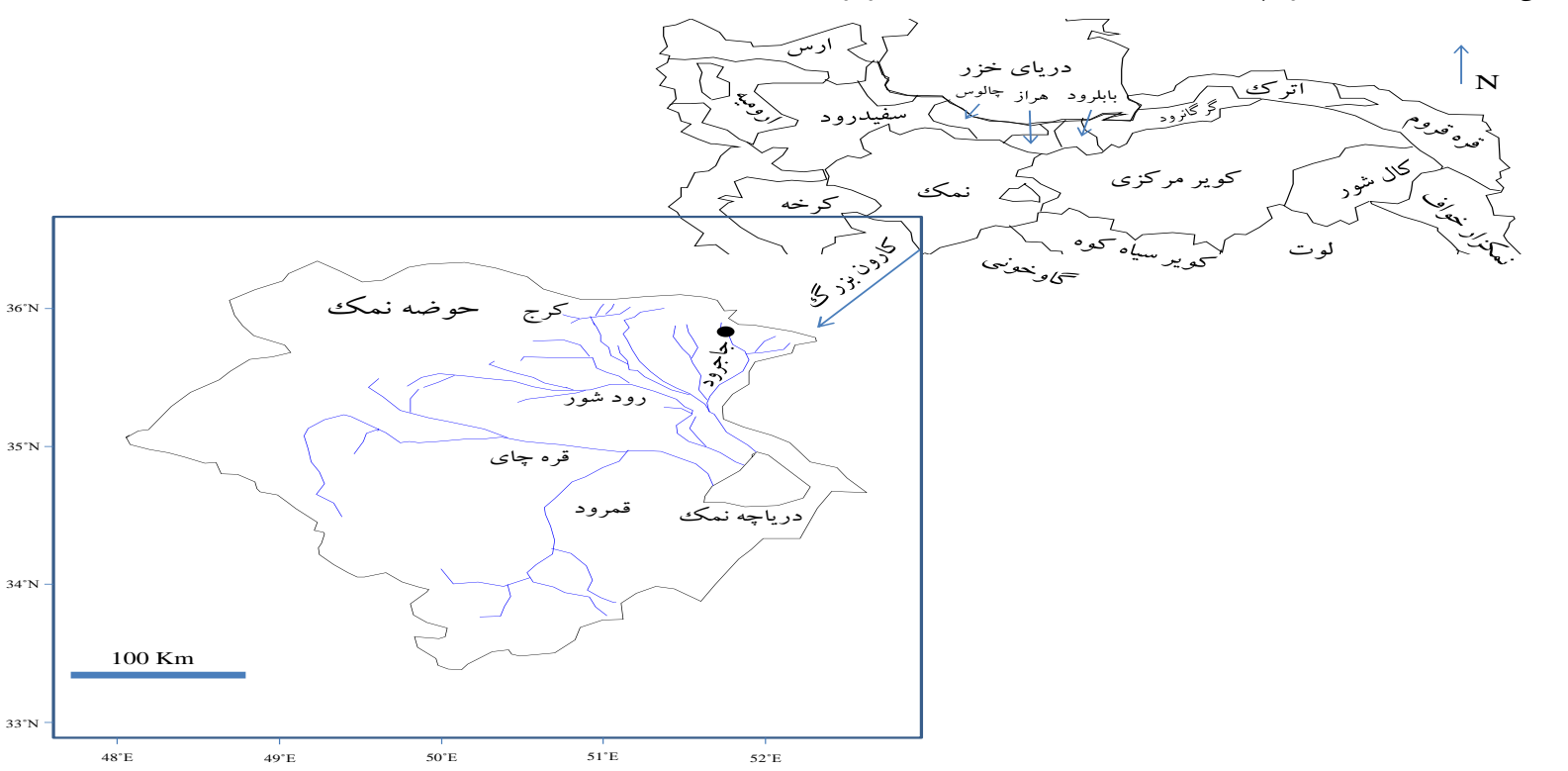

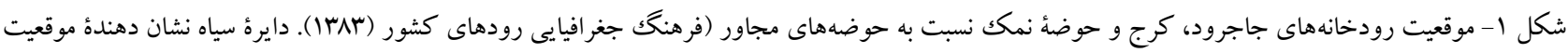
تقريبى نمونهبردارى است.

Fig. 1. Position of the Jajrud and Karaj Rivers and Namak Lake basin relative to adjacent basins (the map is produced based on data provided in "the Gazetteer of rivers in the I.R. of Iran, (2005). The black circle denotes the approximate sampling locality.

ميكروليتر آنزيم پيليمراز (500U; www.sinaclon.com) و r

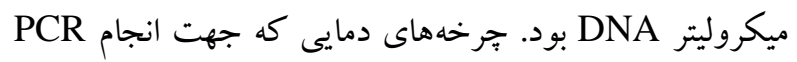

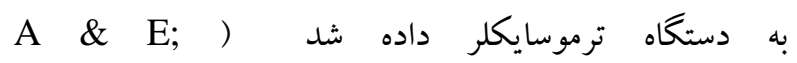
شامل يك مرحله بهمدت · ل دقيقه در

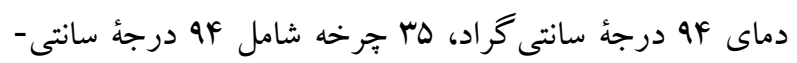

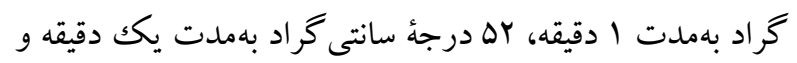
Vr درجة سانتى گراد بهمدت ا دقيقه و در نهايت يكك مرحله

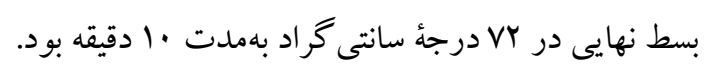
پس إز تكثير ناحية كنترلى و بررسى موفقيت عمل تكثير، له نمونه

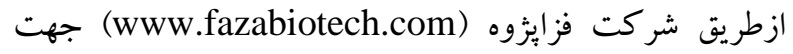
تعيين توالى به خارج از كشور ارسال شدند. با توجه به اينكه

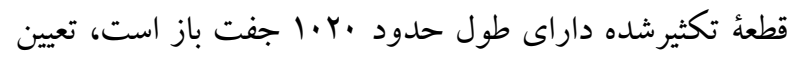

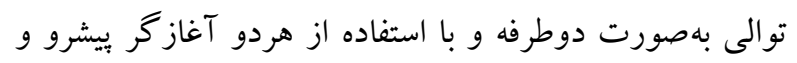
بسرو انجام شد. براى ويرايش توالىها از نرمافزار Bioedit V7.0.0 استفاده

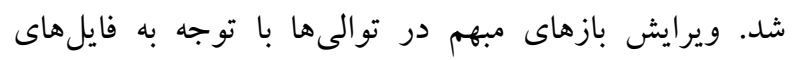

براى استخراج DNA از روش 100/200 Chelex استفاده شد (Estoup et al., 1996) براى انجام اين مطالعه از ناحئ كنترلى ميتو كندرى (D-Loop) كه از توالىهاى اينترون يا لهائ بدون كاركرد محسوب مىشود و بهدليل ضريب جهش بـ بلاتر

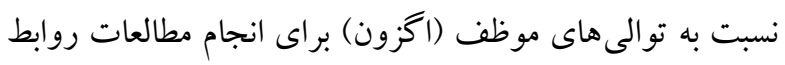

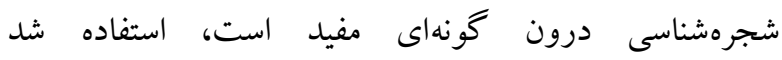

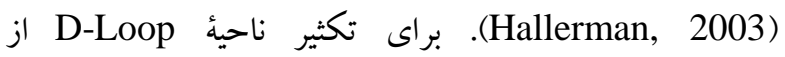
(5'-

BrtD-F2O آغاز گرهاى

\section{BrtD-R20 , GAGATTTTAACTCCCACCCT-3')} (5'-TAGGGTCCATCTTAACAGCT-3') يادشده را بلطور كامل تكثير مىكنند، استفاده شد (Hashemzadeh Segherloo et al., 2012)

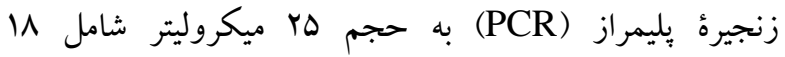

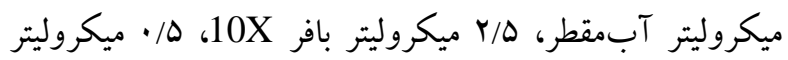

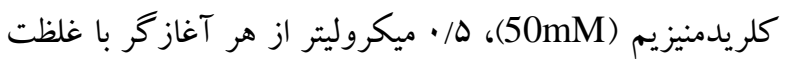

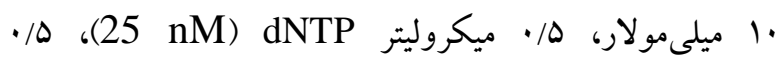


ماهى Salmo trutta macrostigma در دارنگاره در گروه شجرهشناسى آدرياتيك قرار گرفت. گروههاى شجرهشناسى

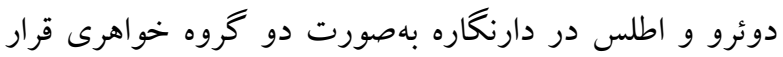

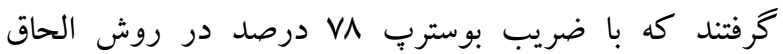

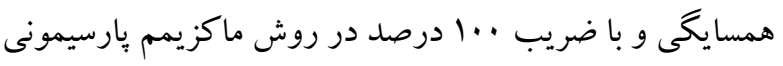

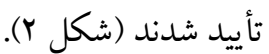
گروه شجرهشناسى مديترانه نيز با ضريب بوسترٍ بـ

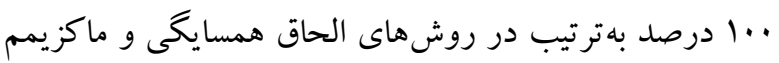

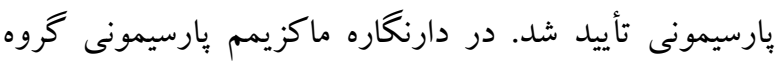
شجرهشناسى آدرياتيك در گروه خواهرى تيرة مديترانهاى قرار گرفت، اما اين رابطه در دارنغاره الحاق همسايكى تأييد نشد.

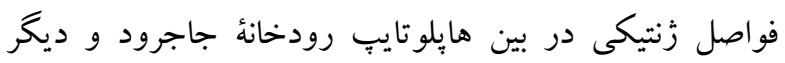

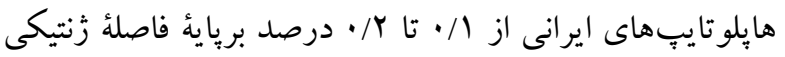

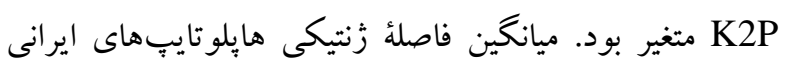

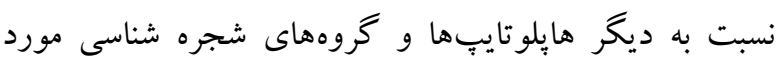

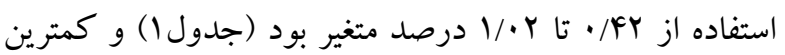

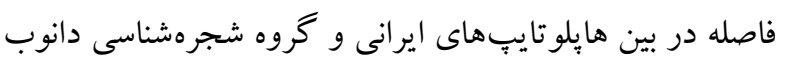
مشاهده شد. بيشترين فاصله نيز در بين هايلوتايٍهاى ايرانى و كروه شجرهشناسى مرمره مشاهده شد (جدول (1). هايلوتايب مشاهدهده با دو هائوتايب خزرى (Ba و

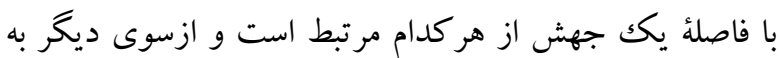
هايلوتايبهاى حوضة آرال (Ar-S. trutta oxianus)، خليج فارس (Da26) و دانوب (Da1a) بلواسطة دو جهش ارتباط دارد (شكل ץ). با توجه به دادههاى موجود در شبكة هايلوتاييى بيشتر ارتباطات هايلوتايبهاى ايرانى و ديخر هايلوتايبهاى

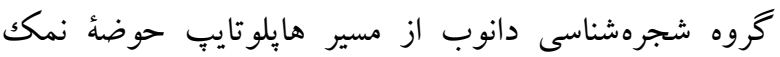
(Na) (مى گذرد (شكل r). در اين مطالعه مشاهده شد كه هايلوتايب موجود در رودخانه

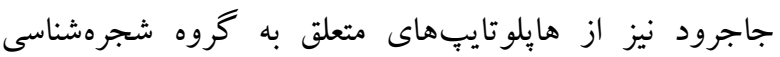
دانوب است كه اين نتيجه با كزارش هاشمزاده سقرلو و

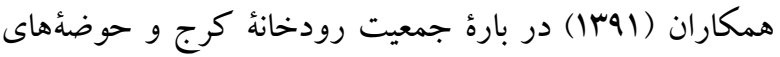
اروميه و خزر مطابقت دارد. در باب منشأ جمعيتهاى حوضئ

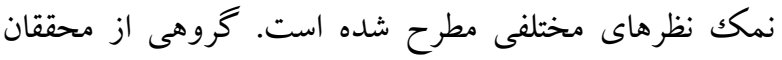
منشأ آنها را از حوضة مديترانه دانستهاند (Coad, 2015).
كروماتو گرام و با توجه به توالىهاى همين گونه كه در مطالعات

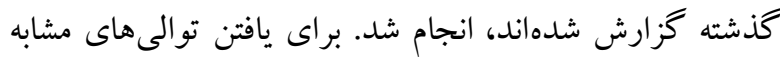
از جستجوى BLAST در بانكك زن (NCBI) استفاده شد (Altschul et al., 1997). براى تطيقدادن يا همرديف كردن

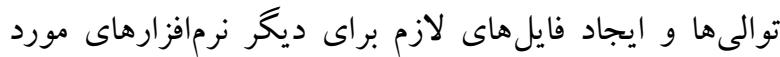

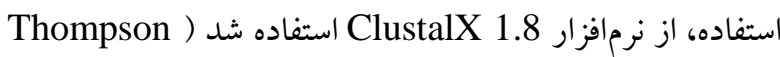
.et al., 2002 براى محاسبة فواصل زنتيكى K2P در بين توالىها و ترسيم

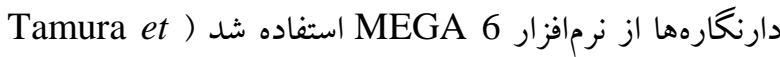

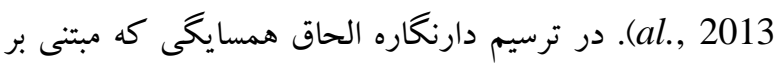

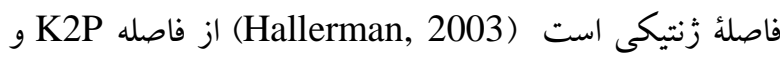

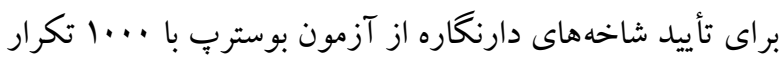

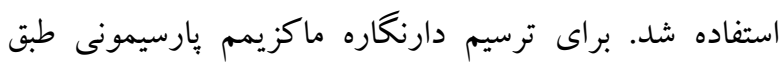

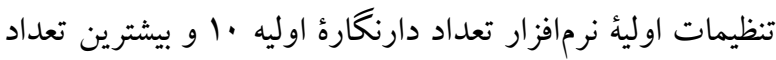
دارنگارههايى كه بايد نرمافزار حفظ مى كرد ... دارنغاره بود و

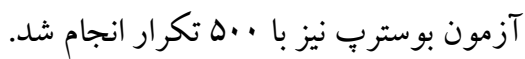

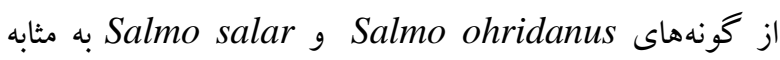
كروههاى خارجى استفاده شد. براى مشاهدة روابط بئ بين هايلو تايبها (اشكال مختلف توالى) شبكةٔ هايلوتاييى با استفاده از نرمافزار TCS1.21 ترسيم شد (Clement et al., 2000). در اين مطالعه فقط يكك هايلوتايب مشاهده شد كه مشابه هايلوتايب گزارششده براى جمعيت قزلآلاى خالقرمز در رودخانه كرج است (جدول (). تركيب نو كلئوتيدى هايلوتايب

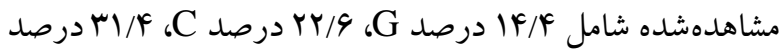
A و و والب درصد T است. A دارنغارههاى ترسيمشده به دو روش الحرصد الحاق همسايگى و ماكزيمم بِارسيمونى داراى شكل تقريباً مشابه بودند (شكل Y) اما دارنخارة ترسيمشده با روش ماكزيمم بارسيمونى برخلاف دازنخاره ترسيمشده با روش الحاق همسايخى فاقد بلى تومى بوده. در هر دو دارنغاره، هايلوتايب جمعيت رودخانهُ جاجرود

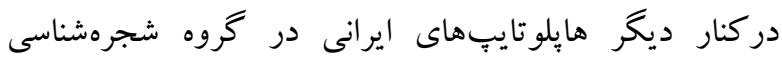
دانوب قرار گرفت و اين گروه با ضرايب ل. ل1 (ماكزيمم پارسيمونى) و و9 درصد (الحاق همسايگى) تأييد شد (شكل Y). 


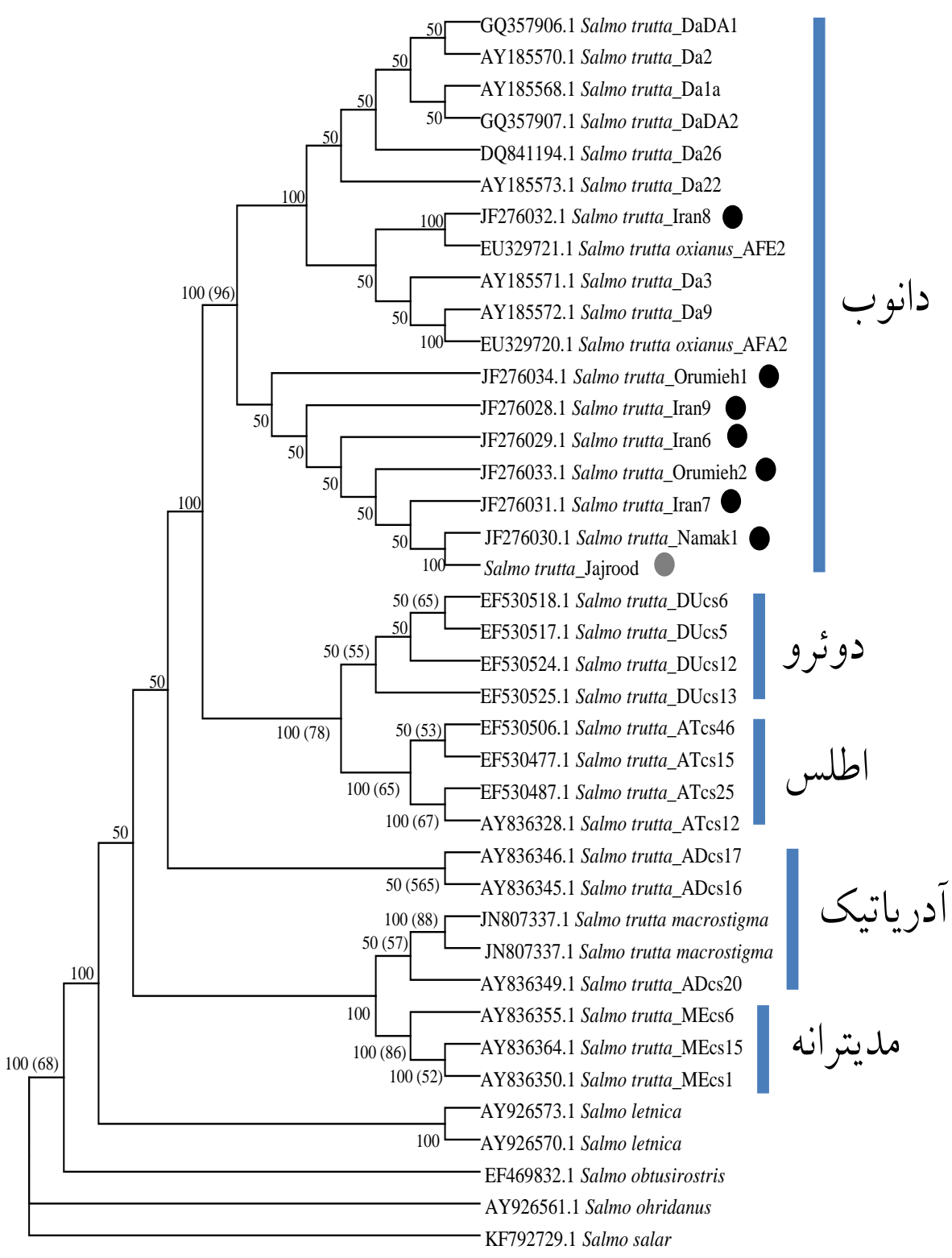

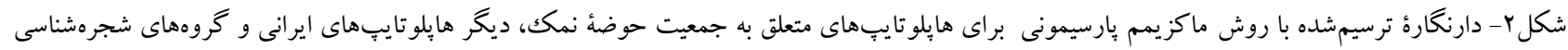

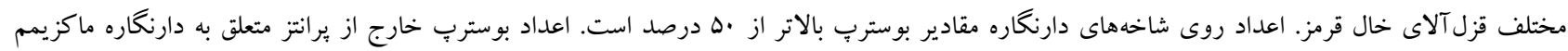

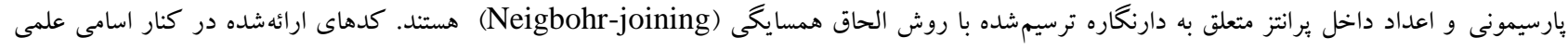

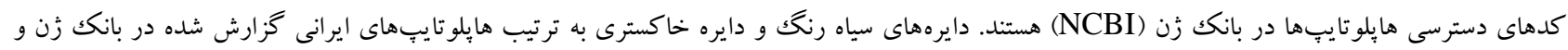

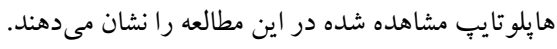

Fig. 2. Maximum Parsimony dendrogram reconstructed for the haplotypes belonging to Namak Basin, other Iranian basin, and other phylogenetic lineages of Brown trout. The figures denoted on the branches are bootstrap values greater than $50 \%$. The figures standing out of the parentheses are bootstrap values for Maximum Parsimony and the figures between parentheses are boot strap values of the Neighbor-Joining threes. The cods before the specific names are GenBank (NCBI) accession nos. The black and grey circles denote previously reported Iranian from the GenBank and the haplotype observed in this study, respectively. 
جدول ا - ميانگين فواصل زنتيكى K2P محاسبه شده براى شجرههاى مختلف قزل آلاى خالقرمز و همجنين گونهاى Salmo trutta macrostigma و

MEGA6 با استفاده از نرمافزار Salmo salar

Table 1. Mean between group K2P genetic distances calculated using MEGA6 for different phylogenetic groups of Brown trout and Salmo trutta macrostigma and S. salar.

\begin{tabular}{|c|c|c|c|c|c|c|c|c|c|}
\hline S. macrostigma & 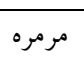 & مديتر انه & 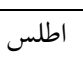 & آدرياتيك & دوئرو & دانوب & ايران & نمكك & كروه شجرهشناسى \\
\hline & & & & & & & & . & نمك \\
\hline & & & & & & & · & $\cdot / I V$ & ايران \\
\hline & & & & & & · & $\cdot / A Y$ & $\cdot / / 49$ & دانوب \\
\hline & & & & & $\cdot$ & $1 / 11$ & $\cdot / M$ & $\cdot / \Lambda \Lambda$ & 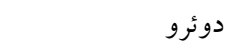 \\
\hline & & & & · & $\cdot / V Y$ & $\cdot / 99$ & $\cdot / \wedge \Delta$ & $\cdot / V q$ & آدرياتيك \\
\hline & & & · & $\cdot / \mathrm{V} a$ & $\cdot / \Delta 9$ & $1 / 1 r$ & $\cdot / \wedge \Delta$ &.$/ 91$ & 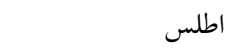 \\
\hline & & · & $\cdot / \mathrm{V}$ & $\cdot / 01$ & $\cdot / M r$ & $1 / 11$ & $\cdot / 9 r$ & •/^9 & مديتر انه \\
\hline & . & .199 & $\cdot / 99$ & $\cdot / A T$ & $\cdot / 9$ & $1 / \cdot r$ & $1 / \cdot r$ & $\cdot / 99$ & 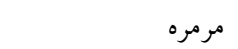 \\
\hline · & .194 &.$/ 4 \Delta$ & $\cdot / \mathrm{Na}$ & $\cdot / \mu q$ & $\cdot / A F$ & $1 / 19$ &.$/ 99$ & $\cdot / 9$ & S. macrostigma \\
\hline$F / 94$ & $F / r$ & $F / V r$ & $F / 9 V$ & $F / F \Delta$ & F/VG & F/Ar & F/VN & $F / V \Lambda$ & S. salar \\
\hline
\end{tabular}

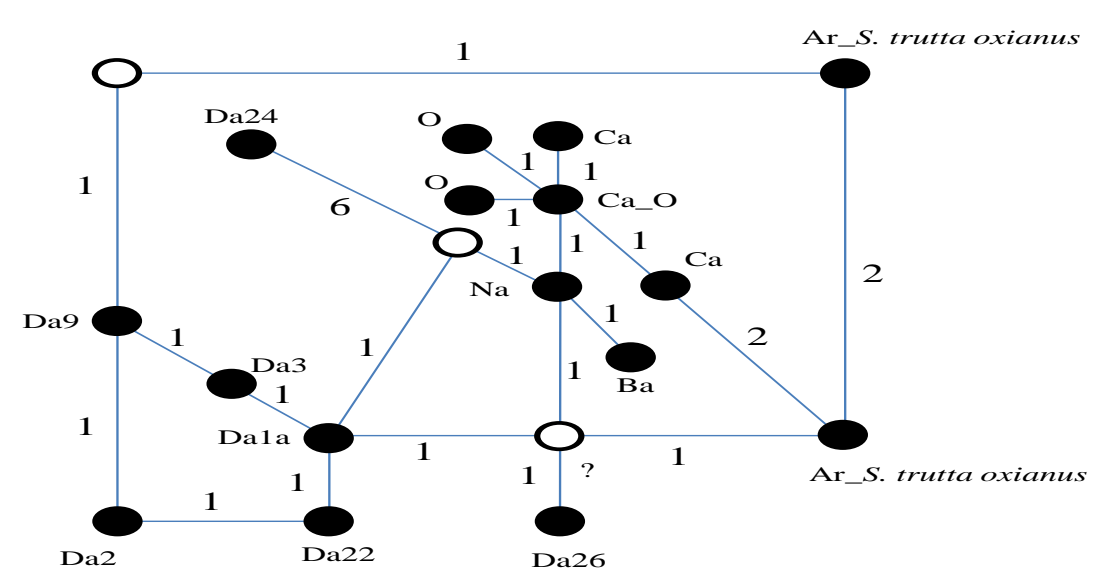

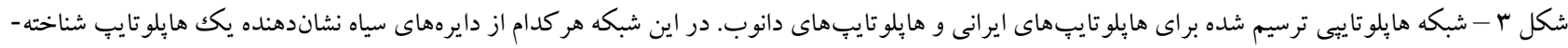

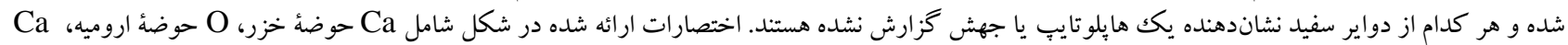

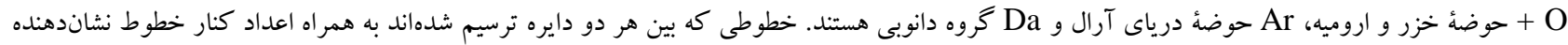

تعداد اختلاف جهشى هستند.

Fig. 3. Haplotype network drawn for the Iranian and Danube haplotypes. On the network each black circle denotes a previously reported haplotype and each white circle shows an unreported haplotype or mutation. The abbreviations are Ca: Caspian basin; O: Orumieh basin; Ca+O: Caspian + Orumieh; Ar: Aral Sea basin; Da: Danube lineage. Each line interconnecting two circles and the related numbers beside it indicate mutational differences.

دارد، ولى ماهى قزل آلاى خالقرمز حوضئ نمك در گروه

$$
\text { شجرهشناسى دانوب قرار كرفته است. }
$$

بحث ديخرى كه درباب جمعيتهاى قزل آلاى خالقرمز وجود دارد نحوه راهيابى آنها به حوضهُ نمكك است؛ به اين مفهوم كه آيا حضور آن در حوضهُ نمكك طبيعى است يا خير. اين موضوع را مىتوان از سه ديدكاه زيستشناختى، روابط زنتيكى و امكانات (زيرساخت هاى ارتباطى و تجهيزات حمل ماهى زنده)، جغر افيا و تاريخجهُ معرفى ماهى در ايران بررسى كرد:
سعادتى (19VVV) دربارهُ منشأ ماهى قزلآلاى خالقرمز حوضه نمكك عنوان مى كند كه اين جمعيتها به ماهى آزاد درياى خزر نزديكى دارد، كه با مشاهدات اين Salmo trutta caspius مطالعه مطابقت دارد. برخى محققان ماهى قزل آلاى خالقرمز حوضة نمك را S. trutta macrostigma دانستهاند ( Coad, 2015) كه نتايج اين مطالعه نظر آنها را رد مى كند، همانطور

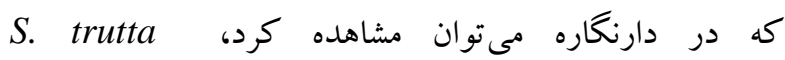
macrostigma 
(Hashemzadeh et al., 2012). نكته جالب دربارة: هايلو تايب حوضةٌ نمكك نحوهُ قرارگيرى و ارتباط آن با ديكر هايلوتايبهاى ايرانى و هايلوتايبهاى دانوبى است (شكل r).

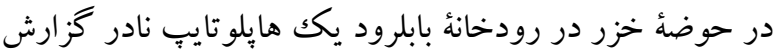
شده است كه هايلوتايب رودخانهُ جاجرود و كرج نسبت به هايلو تايب يادشده و هابلو تايب معمولى حوضهٔ خزر جايگاه حد واسط دارد؛ به اين مفهوم كه مسير جهش از هايلوتايب معمولى خزر پِ إز عبور از هايلو تايب نمكك به هايلو تايب بابلرود (Ba) مىرسد (شكل ازسوى ديخر، اين هايلوتايب با يك واسطه به هإيلوتايبهاى خليج فارس (Da26)، دانوب و حوضةٔ آرال (Ar) متصل است كه مى تواند نشاندهندة قدمت اين هايلوتايب باشد؛ زيرا بريّائ اصول و معيارهاى ترسيم شبكة هايلوتاييى، هايلوتايبهايى كه

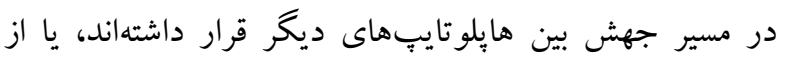
ارتباطات بيشترى برخوردارند، قديمى محسوب مىشوند و

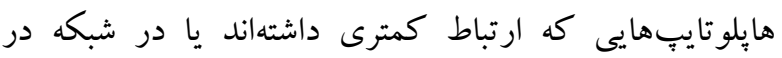

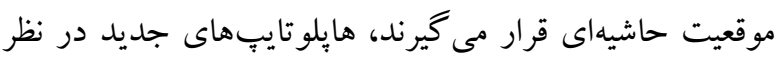
كرفته مىشوند (Freeland, 2005). در مجموع، مىتوان از مشاهدات اين مطالعه و ديخر مطالعات (هرات

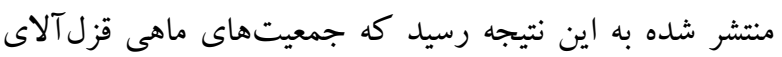

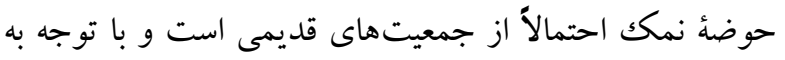

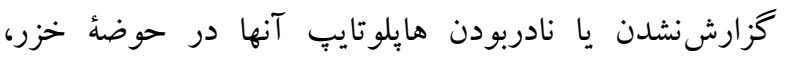
احتمال انتقال مصنوعى آنها به اين حوضهٔ بعيد به نظر مىرسد،

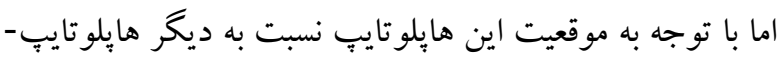

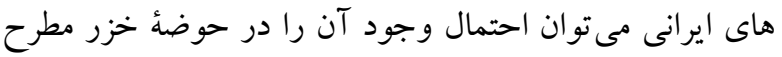
كرد. اثبات اين مسئله و مسير تاريخى راهيابى جمعيت حوضئ نمك نيازمند مطالعه ديخر جمعيتهاى حوضهُ خزر بهويزه در رودخانهاى مسير هراز، سردابرود و شاخههاى رودخانهُ جالوس

\section{سياسگز ارى}

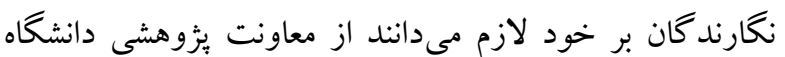
شهر كرد، يزوهشكده علوم محيطى دانشكاه شهيدبهشتى، دفتر تنوع زيستى و حيات وحش سازمان حفاظت محيط زيست و ادارٔ كل محيط زيست استان تهران كه امكان انجام اين مطالعه را فراهم كردند، قدردانى كنند. اين يُزوهش با استفاده از يزوهانه
در ديدگاه اول، ماهى قزل آلاى خالقرمز، از نظر زيستشناسى و نيازهاى مرتبط، گونه بسيار حساسى است كه براى زنده ماندن

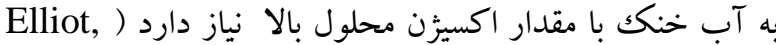
1994) و درصورت انتقال بايد در شرايط خاص و در زمان محدودى منتقل شود تا بتوان ماهى يادشده را بهصورت زنده از بكك زيست گاه به زيست گاه ديخر انتقال داد. با درنظر گرفتن وضعيت راهها و مسيرهاى ارتباطى در ايران در زمان مورد ادعا (اواسط قرن نوزدهم) و با توجه به امكانات ترابرى و تجهيزات لازم براى زندهنگاهداشتن ماهى، احتمال اينكه اين انتقال بهدست انسان صورت گرفته باشد بعيد بهنظر مىرسد؛ زيرا درصورت استفاده از وسائل ترابرى مرسوم در زمان يادشده و با توجه به وضعيت مسيرهاى ارتباطى، عمل انتقال ماهى قزل آلا در بازه زمانى مناسب براى انتقال ماهى زنده دوراز انتظار است. ازسوى ديخر، باتوجه به جغر افياى يراكنش رودخانهاى حوضهٔ خزر و با فرض وجود جمعيتهاى خزرى در همة رودخانهاى اين حوضئ جند مسير انتقال شامل انتقال از رودخانه هراز به

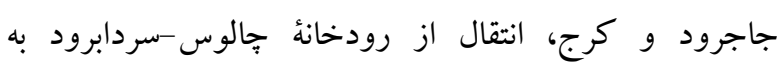

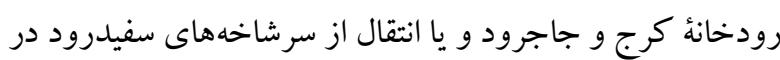

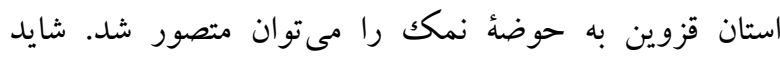
نزديكك ترين و محتمل ترين مسير انتقال از طريق رودخانه هراز باشد، زيرا اين رودخانه و سرشاخههاى آن در باركك ملى لار با سرشاخه هاى رودخانه جاجرود فاصله كمترى دارند. باينحال، انتقال ماهى با امكانات و در زمان يادشده با توجه به كوهستانى روانى بودن اين مناطق بعيد به نظر مىرسد. درباب هايلوتايب مشاهدهده در ماهى قزل آلاى خالقرمز رودخانه هاى جاجرود و كرج بايد گفت كه هايلو تايب يادشده از هايلوتايبٍهاى قديمى حوضة خزر است و در مطالعهُ نمونههاى رودخانه هراز، بابلرود و شيرينرود حوضهٔ خزر (هاشمزاده سقرلو و همكاران (qجا) هايلوتايٍ يادشده در حوضهُ خزر مشاهده نشده است. با توجه به اين كه هإِلو تايب حوضةٌ نمكك در رودخانه هاى يادشده مشاهده نشده است، مىتوان آن را يكى از هابِلوتايٍهاى نادر در حوضة خزر دانست و بههميندليل نيز شايد بتوان ادعا نمود كه انتقال يكك هايلوتايبٍ نادر به دست انسان به حوضئ نمكك دور از انتظار و بعيد به نظر مىرسد زيرا در همة رودخانههاى مطالعهده در حوضهُ خزر و اروميه يك هايلو تايب معمولى مشتر كك مشاهده شده است رونا 


\begin{abstract}
Altschul, S.F., Madden, T. L., Schäffer, A.A., Zhang, J., Zhang, Z., Miller, W. and Lipman, D.J. 1997. Gapped BLAST and PSI-BLAST: a new generation of protein database search programs. -Nucleic Acids Res. 25(17): 33893402.
\end{abstract}

Bernatchez, L. 2001. The evolutionary history of brown trout (Salmo trutta L.) inferred from phylogeographic, nested clade, and mismatch analyses of mitochondrial DNA variation. - Evolution 55: 351-379.

Clement, M., Posada, D. \& Crandall, K.A. 2000. TCS: a computer program to estimate gene genologies. - Mol. Ecology 9(10): 1657-1660.

Coad, B. 2015. Freshwater Fishes of Iran. Available at http://www.briancoad.com/contents.

Elliot, J.M. 1994. Quantitative Ecology and the Brown Trout. Oxford: Oxford University Press.

Estoup, A., Largiad'er, C.R., Perrot, E. and Chourrout, D. 1996. Rapid one tube DNA extraction for reliable PCR detection of fish polymorphic markers and transgenes. - Mol. Marine Biol. Biotech. 5: 295-298.

Freeland, J.R. 2005. Molecular Ecology. Chichester: John Wiley \& Sons, Ltd.

Hallerman, E.M. 2003. Population genetics: principles and applications for fisheries scientists. -American Fisheries Society.

Hashemzadeh Segherloo, I., Farahmand, H., Abdoli, A., Bernatchez, L., Primmer, C.R.,
Swatdipong, A., Karami, M. and Khalili, B. 2012. Phylogenetic status of brown trout Salmo trutta populations in five rivers from the southern Caspian Sea and two inland lake basins, Iran: a morphogenetic approach. - J. Fish Biol. 81: 14791500 .

Maric, S., Susnik, S., Simonovi'c, P. and Snoj, A. 2006. Phylogeographic study of brown trout from Serbia, based on mitochondrial DNA control region analysis. - Genetics Selection Evolution 38: 411-430.

Saadati, M.A.G. 1977. Taxonomy and Distribution of the Freshwater Fishes of Iran. MS Thesis. Colorado State University: Fort Collins, Co, USA.

Suarez, J., Bautista, J.M., Almod'ovar, A. and Machordom, A. 2001. Evolution of the mitochondrial control region in Palaearctic brown trout (Salmo trutta) populations: the biogeographical role of the Iberian Peninsula. Heredity 87: 198-206.

Tamura, K., Stecher, G., Peterson, D., Filipski, A. and Kumar, S. 2013. MEGA6: Molecular Evolutionary Genetics Analysis version 6.0. Mol. Biol. Evolution 30: 2725-2729.

Thompson, J.D., Gibson, T. and Higgins, D.G. 2002. Multiple sequence alignment using ClustalW and ClustalX. - Current Protocols in Bioinformatics 2-3. 
Khosravani Asl, Q., Hashemzade, I., PirAli, I. and Abdoli, A. 2016. The phylogenetic position of Brown trout (Salmo trutta) in the Jajrud River using D-Loop sequence. - Nova Biol. Rep. 3: 39-47.

خسروانىاصل، غ.، هاشمزاده، ا،، ييرعلى، ا. و عبدلى، ا. هوسا. شجرهشناسى ماهى قزل آلاى خالقرمز (Salmo trutta L. 1758) رودخانه جاجرود

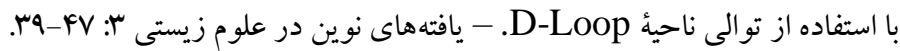

